\title{
Philosophical Reflection of the Concept of "Borders" in Modern Culturechinese Performing
}

\section{Reflexión filosófica del concepto de "fronteras" en la cultura moderna}

\section{Du Ying}

postgraduate student department of the Philosophy, Culturology Science of Science, Belgorod State Institute of arts and culture, Koroleva St., 7, Belgorod, 308000, Russia.

Belgorod State Institute of Arts and Culture; Hulunbuir University

ORCID iD 0000-0003-3838-6183

\section{Kuznetsova A.V.}

Candidate of the philosophical sciences, professor of the fortepiano department; Belgorod State Institute of Art and Culture, 7 Koroleva str., Belgorod, Russia, 308000.

https://orcid.org/0000-0002-1178-458X

\section{Kalinina G. N.}

Doctor of the Philosophical Sciences, Professor of the Philosophy department, Culturology Science of Science; Belgorod State Institute of Arts and Culture 7, Koroleva str., Belgorod, Russia, 308000.

https://orcid.org/0000-0002-6825-9532

\section{* Correspondence}

Email: 450382671@qq.com

\section{Citation:}

DuYing, Kuznetsova A.V., \& Kalinina G. N (2021). Philosophical Reflection of the Concept of "Borders" in Modern Culturechinese Performing. Propósitos y Representaciones, 9 (SPE3), e1151. Doi: http://dx.doi.org/10.20511/pyr2021.v9nSPE3.1151 


\begin{abstract}
Objective: philosophical reflection problems of the frontiers of science, knowledge and creativity in the modern intercultural integration; rationale for new interpretations and understanding of the concept "border" providing an integrative model for science and culture, which, in turn, implies the unacceptability of Orthodox approaches, and rigid demarcation between different spheres of cultural production. This explains the need to develop a "rational-reflexive culture" that meets the new demands of modern society. Research procedure and methods: the theoretical and methodological research of the work is based on the works of classics of Western and domestic philosophical, cultural, historical, and other thought in the field of studying the essence of social and cognitive phenomena; classical and non-classical methodological paradigms of understanding the concept of "borders" in ontological, epistemological grounds and socio-cultural dynamics are used. The main method is the classical method of dialectics, associated with the consideration of things in a broad ontological, epistemological and cultural-historical context; a method of comparative analysis, a combination of historical and logical, concrete-universal, phenomenological and systemic principles, a thesaurus approach. The results of the study: analyzed new meanings of the concept "border", "rational - reflexive culture" in knowledge and creativity; proven illegality model "narrow" technological oriented science and culture to the detriment of the spiritual nature of man; it is proved that as the modern world blurs the lines of demarcation in science, culture, art, insofar exacerbated the task of establishing priorities, implying the transition from a world of "pure rationality" to the life world of man; an optimal model of the conjugacy of all forms of human cognitive and creative activity in culture is proposed, due to the genetic connection of rational and other mental and cognitive forms of world development. Theoretical / practical significance consists in the justification and author's interpretation of the new understanding of the boundaries of science-culture-man; in proving the need to expand the boundaries of science in ontological and epistemological grounds to the "borders of culture"; implemented criticism of the technogenic interpretation of science (science as "sciepse"), with the connection with which the thesis is justified about the inexpediency of excessive rationalization of knowledge and cognition to the detriment of other ways and forms of world development.
\end{abstract}

Key words: borders, rational-reflexive culture, man, knowledge, cognition, creativity, technogenic science, borders, tradition, multiculturalism, integration, network world order, "life world", humanization, mental and cognitive forms.

\title{
Resumen
}

Objetivo: problemas de reflexión filosófica de las fronteras de la ciencia, el conocimiento y la creatividad en la integración intercultural moderna; justificación de nuevas interpretaciones y comprensión del concepto "frontera" proporcionando un modelo integrador para la ciencia y la cultura, lo que, a su vez, implica la inaceptabilidad de los enfoques ortodoxos, y una demarcación rígida entre las diferentes esferas de la producción cultural. Esto explica la necesidad de desarrollar una "cultura racional-reflexiva" que responda a las nuevas demandas de la sociedad moderna. Procedimiento y métodos de investigación: la investigación teórica y metodológica del trabajo se basa en los trabajos de los clásicos del pensamiento filosófico, cultural, histórico y de otro tipo occidental y doméstico en el campo del estudio de la esencia de los fenómenos sociales y cognitivos; Se utilizan paradigmas metodológicos clásicos y no clásicos para entender el concepto de "fronteras" en bases ontológicas, epistemológicas y dinámicas socioculturales. El método principal es el método clásico de la dialéctica, asociado a la consideración de las cosas en un amplio contexto ontológico, epistemológico y cultural-histórico; un método de análisis comparativo, una combinación de principios históricos y lógicos, universales concretos, fenomenológicos y sistémicos, un enfoque de tesauro. Los resultados del estudio: analizaron nuevos significados del concepto "frontera", "cultura racional - reflexiva" en el conocimiento y la creatividad; Modelo de ilegalidad probada "estrecha" orientada a la ciencia y la cultura tecnológica en detrimento de la naturaleza espiritual del hombre; Está comprobado que en la medida en que el mundo moderno difumina las líneas de demarcación en ciencia, cultura, arte, en la medida se exacerba la tarea de establecer prioridades, lo que implica la transición de un mundo de "pura racionalidad" al mundo de la vida del hombre; Se propone un modelo óptimo de conjugación de 
todas las formas de actividad cognitiva y creativa humana en la cultura, debido a la conexión genética de las formas racionales y mentales y cognitivas del desarrollo mundial. El significado teórico / práctico consiste en la justificación e interpretación del autor de la nueva comprensión de los límites ciencia-cultura-hombre; al demostrar la necesidad de expandir los límites de la ciencia en bases ontológicas y epistemológicas hasta las "fronteras de la cultura"; Se implementó la crítica a la interpretación tecnogénica de la ciencia (ciencia como "sciepse"), con la conexión con la que se justifica la tesis sobre la inoperancia de una racionalización excesiva del conocimiento y la cognición en detrimento de otras vías y formas de desarrollo mundial.

Palabras clave: fronteras, cultura racional-reflexiva, hombre, conocimiento, cognición, creatividad, ciencia tecnogénica, fronteras, tradición, multiculturalismo, integración, orden mundial en red, "mundo de la vida", humanización, formas mentales y cognitivas.

\section{Introduction}

The problem of researching and its actuality is due to situational specific of today's world. In particular that in condition of a polyculture world order, forms and models of world perception the concept "borders" opens up a new facets and perspectives of its studying. Time reveals new qualitative characteristics of the boundaries of knowledge, cognition, creativity - depending on the cultural context, systemic transformations of human communication with the world. Hence, the task of a new interpretation of the boundaries and meanings of human existence is actualized in accordance with existential status.

\section{The analysis of literary sources showed}

The analysis of literary sources showed: The problem of analytics of the concept of "borders", interpretation of human creative potential in culture was considered in the classical non-classical philosophy of culture. In this regard, it is interesting to note that the implementation of the historical, philosophical and methodological explication of philosophy as a form of rationalism, different from science, required support to the works of the great German classics I. Kant, G. Hegel, M. Weber, G. Gadamer, E. Husserl, W. Dilthey, M. Heidegger, F. Schelling A. Schopenhauer, O. Spengler, K. Jaspers, of which , in fact, the whole "non-classical" conceptualization of the problem has grown (Gadamer, 1977; Hegel, 1993; Molchanova, 2002; Diltej, 1995; Kant, 1964; Kuhn, 1975; Spengler,1993; Yang, 2016 ). Also, this topic is thoroughly presented in the post-positivist discourse, concepts of post-analytical and post-structuralist philosophy (Derrida, 2000; Lakatos, 1993; Popper, 1992 ) The works of F. Nietzsche, W. Dilthey, S. Kierkegaard, F. Schleiermacher, E. Husserl, M. Heidegger, G.-G. Gadamer, K. Jaspers, J.-P. Sartre, M. Buber, J. Lacroix, H. Ortega y Gasset and others (Gadamer, 1977; Husserl, 2002; Deleuze, 2001; Derrida, 2000; Diltej, 1995).

Questions of the intellectual potential of mankind, strategies of scientific research were solved by such authors as J. Bernal, M. Korach, R. Oppenheimer, D. Price, J. Needam, R.L.M. Sing, P.L. Kapitsa, N.N. Semenov, V.N. Stoletov. Within the framework of the problem of expanding the human reserves of science, the state of blurring (up to complete disappearance) of boundaries between categories of people engaged in science was predicted (Kulikova, 2009; Kulikova, 2010). The critical program of M.M. Bakhtina points to the limitations of traditional epistemology (Bakhtin, 2000), and the idea of "developing harmony" by V.N. Sagatovsky is considered an ideal model of the world and man (Sagatovsky, 2011).

\section{Main part. The concept of "borders" in the conditions of destruction of technogenic civilization.}

The obvious destructive features of a technogenic civilization, where science plays the role of an innovative sociocode, serve as a sufficient basis for an epistemological program of limiting the competence of modern rationality. Its solution lies in the timely identification and prompt resolution of global socially significant problems of a special "timed" class with the 
involvement of the entire complex of knowledge and increasing the social responsibility of scientists. Thus, the task of investigating the boundaries beyond which the work of science cannot (and should not) extend, not so much in the search for limitations of the competence of reason, as in the horizon of the scientist's moral responsibility (Kalinina \& Rimskiy, 2012; Kalinina, 2012).

In addition, the extreme rationalization of technogenic culture in a sense stimulates the socalled "psychological epidemics", when the "irrational" displaced by excessive rationalization develops into the stage of "occult renaissance" or "religious revival", accompanied by the permissiveness of "no shores", a deviation from the principle of "no harm" with negative consequences affecting the sphere of human spirituality and corporeality. Taking into account these realities, the problem of the boundaries of knowledge (and not just scientific) resonates sharply with the culture of rationality and the culture of boundaries, because, according to $\mathrm{M}$. Bakhtin, "all culture is located on the borders" (Bakhtin, 2000). In other words, in the history of science and culture, the problem of boundaries as a measure of what is possible and permissible in (in relation to the research activity of a scientist) has the character of not only a purely theoretical, but also a vital and practical task, acquiring additional timeliness and acuteness. In a dynamic, unstable, rapidly changing world (Kalinina \& Rimskiy, 2012).

\section{Reflection of the mismatch between science and the basic values of culture: the situational specificity of the process.}

Today, at the epicenter of the philosophy of science, there remains the problem of the potential and status of a scientific phenomenon, which is formulated as a situation of tragic disagreement between science and the basic values of culture (Kalinina \& Rimskiy, 2012). Philosophical reflection on the boundaries of science and "other" knowledge is undoubtedly relevant also for understanding the fact that there is no world of "pure" science and "pure" rationalism. Even at a superficial glance, it is obvious: the "world of science" includes, so to speak, "filmed form" all the diversity of forms of knowledge, different from the "purely scientific." What has been said about the conjugation of mental-cognitive formations does not mean the absolutization of the absence of epistemological demarcation between them. That (Kalinina, 2012). We agree that "... a radical methodological innovation, according to which it is most expedient to put in the basis of a theoretical construction not a series of prescriptive laws, but an optimal number of restrictions, supplemented by the requirement to develop" rules of scientific honesty "... still sounds relevant" (Kalinina, 2012).

\section{The practical and spiritual value of creativity in creating a new image of culture (based on the experience of the national Chinese tradition)}

We wrote that "... against the background of the glaring contradictions of the modern world order, the systemic crisis of man and other destructions, music has a positive force dynamic of the reorganization of societies, helping to overcome the existential gap in the "human situation" (Duying, 2019). In principle, we agree with the Mongolian scientist, musician Nasu, who says that "... the typical constructive characteristics of the Mongolian folk musical instrument morinhuur, which form its qualitative specificity as an exponent of the Mongolian ethnos (including the features of sound images characteristic of early gaming practices Mongolian song art " (Nsu, 2019). In addition, we, following the Chinese researchers, draw attention to the fact that" in spite of the multi-composition of the musical sphere, expressed in species, genre and stylistic diversity, in the musical system of ancient China both in antiquity and today, folk tradition occupies the main positions. It was folk singing practices that originally emerged from folklore, served as a "starting point" for the formation of a national Chinese culture, a component of which, as we have shown, is folk musical creativity " (Aotengenhuar, 2020). Indeed, "The unique musical layer of folk music musical and performing culture, while continuing to be carefully preserved (and honored) in the modern musical and educational system of the PRC, constitutes its dominant basis, centering the state paradigm of musical education and ethical and aesthetic education of modern Chinese youth" (Aotengenhuar, 2020). In our opinion, largely due to this approach, including on the part of the state cultural policy, the ideological origins of the Chinese mentality itself are 
developing and strengthening, while simultaneously exerting a significant influence on the enrichment of similar musical practices in other cultures. At the same time, it is obvious that one cannot fail to see signs of alarming symptoms regarding "national cultures", when, say, the steady globalization of life and everyday life, cultural and spiritual preferences rooted in the history and "genetics" of specific peoples, have a destructive effect on traditional nomadic civilizations, affecting, or even undermining the foundations of its culture.

In conclusion, a generalization is given about the importance of philosophical and ethical reflection on the boundaries of science and culture from the standpoint of the anthropocosmic perspectives of mankind, which is necessary to resolve the issue of measures of the possible and acceptable in the scientific and cultural practices of our time.

\section{Conclusion}

The implementation of the main goal and objectives of the study allows us to conclude the following: one of the results of our own analysis of the problems considered in this article was a generalization about the legitimacy of understanding the concept of the boundaries of science, from the point of view of conjugation of science and culture. By bringing these boundaries closer together, we simultaneously emphasize their "sliding" nature. This approach allows us to analyze all the cognitive diversity of consciousness, activity and communication, and, therefore, to better understand the nature, place and role of science for a person and his "life world". First of all, those where we are talking about the need for a transition to a new concept of understanding science and its role in society and, thereby, in culture, on the inclusion of humanitarian and social disciplines and approaches in science. All of these seem to us to be extremely timely and topical - especially if we take into account the depressing circumstance of disagreement between modern science and the basic values of culture. Thus, we see that the problem of the boundaries of knowledge, and broader philosophical reflection of reason, continues to be an urgent interdisciplinary sphere in the context of the search for ontological foundations of knowledge and cognition and creativity, as well as the place of man in culture.

\section{References}

Aotengenhuar, Adan, Sum Ber, G.N. Kalinina Axiology and concept - images of the Chinese musical culture // Publishing Group, 2020. P. 82.

Bakhtin M. M. Author and hero: the philosophical foundations of the Humanities / M. Bakhtin. Spb. $-2000 .-345$ p.

Deleuze G. Empiricism and subjectivity: the experience of human nature to Yuma / G. Deleuzem.: per SE, 2001.

Derrida J. Structure, sign and play in the discourse of the human sciences/ J. Derrida//French semiotics: From structuralism to poststrukturalism. -M.: Progress, 2000. -P. 407-427.

Diltej V. ideology types and their detection in metaphysical systems//Culturology. Inthetwentiethcentury. Anthology. -M.: Lawyer". -1995. -703 p.

Duying.Chinese performing culture and national features of "Chinese performance" / / JCR. 2019; 6(6). Pp. 427-429.

Gadamer G. Truth and method / G. Gadamer. -M.: knowledge, 1977. -154 p.

Hegel G. Philosophy of history. Lane. A.M. Vodena. -Spb: Nauka, 1993. -470 p.

Heidegger M. Question about technology / time and Genesis: articles and speeches: Lane. with it. M.: Republic, 1993. -P. 232-234.

Husserl. The crisis of European Sciences and transcendental Phenomenology. V.I. Molchanova//Logos. 1 (32) 2002, p. 132-148.

Kalinina G.N. the frontiers of science and converted forms of knowledge: monograph/ G.N. Kalinina, 2012. -292 p.

Kalinina G.N., Rimskiy V.P. Self-positing science and esterified forms of knowledge//scientific statements, Technopark. Series "Philosophy. Sociology. The law of the sea ". -No. 20 (139). 22.-Belgorod, 2012. -P. 28-39.

Kant I. Critique of pure reason//Kant and op. cit. in 6 t. m., 1964. -590 p. 
Kuhn T. The structure of scientific revolutions. M., 1975. -288 p.

Kulikova T.V. Existential-anthropological meaning border/T.V. Kulikova // Herald of the Nizhny Novgorod University. No. 3. Part 1. -N. Novgorod, 2010. -P. 369-375.

Kulikova T.V. Philosophy "borders": monograph [text]/T.V. Kulikova. -N. Novgorod, 2009. -192 p.

Lakatos I. With programs of T. Kuhn and Popper//From logical positivism to postopositivism. -M.: NIFU-Inion, 1993. -P. 178-182.

Nsu. Production technologies of the Mongolian ethnic musical instrument Morin Huur: traditions and modernity (philosophical problematization) / / JCR. 2019; 6(6). P 430-432.

Popper K. To open society and its enemies/K. Popper. -M.: mysl, 1992. -334 p.

Sagatovsky V.N. Philosophical categories. H. I. Ontology. - Spb., 2011. -127 p.

Spengler O. The Decline in Europe. Essays on the morphology of world history/o. Spengler. -M.: Express, 1993. -540 p 22. Schopenhauer D. Full. sobr. op. T. 2. /d. Schopenhauer. -M.: Lawyer, 1999. $-370 \mathrm{p}$.

Yang Bo Dynamics of professional solo Peng in China: education, pedagogical and performing principles. Dis. K. art historian. Nizhny Novgorod, 2016. 